\section{Climate Change and Distribution Shifts in Marine Fishes}

\begin{abstract}
Allison L. Perry, ${ }^{1 *}$ Paula J. Low ${ }^{2} \dagger$ Jim R. Ellis, ${ }^{2}$ John D. Reynolds ${ }^{1 *}$
We show that the distributions of both exploited and nonexploited North Sea fishes have responded markedly to recent increases in sea temperature, with nearly two-thirds of species shifting in mean latitude or depth or both over 25 years. For species with northerly or southerly range margins in the North Sea, half have shown boundary shifts with warming, and all but one shifted northward. Species with shifting distributions have faster life cycles and smaller body sizes than nonshifting species. Further temperature rises are likely to have profound impacts on commercial fisheries through continued shifts in distribution and alterations in community interactions.
\end{abstract}

Climate change is predicted to drive species ranges toward the poles (1), potentially resulting in widespread extinctions where dispersal capabilities are limited or suitable habitat is unavailable (2). For fishes, climate change may strongly influence distribution and abundance $(3,4)$ through changes in growth, survival, reproduction, or responses to changes at other trophic levels $(5,6)$. These changes may have impacts on the nature and value of commercial fisheries. Species-specific responses are likely to vary according to rates of population turnover. Fish species with more rapid turnover of generations may show the most rapid demographic responses to temperature changes, resulting in stronger distributional responses to warming. We tested for large-scale, long-term, climate-related changes in marine fish distributions and examined whether the distributions of species with fast generation times and associated life history characteristics are particularly responsive to temperature changes.

We studied the demersal (bottom-living) fish assemblage in the North Sea. This group is composed of more than 90 species with varied biogeographical origins and distribution patterns. North Sea waters have warmed by an average of $0.6^{\circ} \mathrm{C}$ between 1962 and 2001 , based on four decadal means before 2001, and by $1.05^{\circ} \mathrm{C}$ from 1977 to 2001 (7), which correspond with our fish survey time series. Survey data were used to calculate catch per unit effort to determine centers of abundance (mean latitudes and depths) for all species and boundary latitudes for those species that have either northerly or southerly range limits in the North Sea (7). No

${ }^{1}$ Centre for Ecology, Evolution and Conservation, School of Biological Sciences, University of East Anglia, Norwich NR4 7TJ, UK. ${ }^{2}$ Centre for Environment, Fisheries and Aquaculture Science, Lowestoft Laboratory, Lowestoft NR33 OHT, UK.

*To whom correspondence should be addressed. E-mail: a.perry@uea.ac.uk (A.L.P.); reynolds@uea.ac.uk (J.D.R.).

$\uparrow$ Present address: University Marine Biological Station Millport, Isle of Cumbrae KA28 OEF, UK. species range was entirely confined to the North Sea. Measures of distribution were regressed against same-year and time-lagged bottom temperatures, and also a composite measure of temperatures, the North Atlantic Oscillation Index, the Gulf Stream Index, and the ratio of abundances of northern and southern calanoid copepod species (7). We also controlled for changes in abundance that may have influenced species distributions (7).

Centers of distribution as measured by mean latitudes shifted in relation to warming for 15 of 36 species (Table 1). These trends were shown by both commercially exploited species [such as Atlantic cod (Gadus morhua)
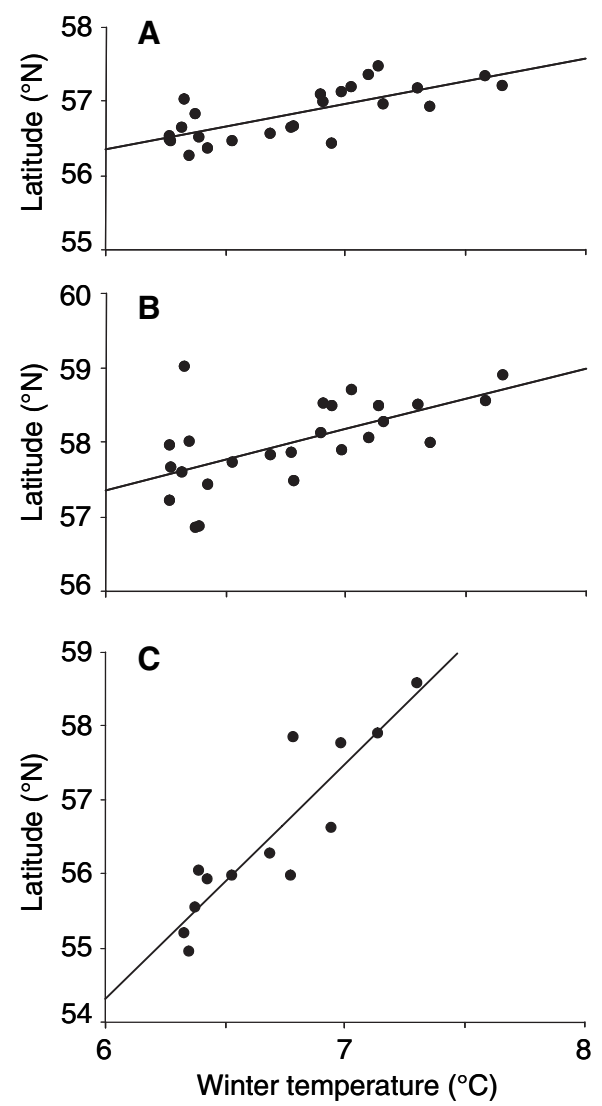

and the common sole (Solea solea)], and by species that are not targeted by fisheries [such as scaldfish (Arnoglossus laterna) and snakeblenny (Lumpenus lampretaeformis)]. Distances moved ranged from 48 to $403 \mathrm{~km}$ (average distance $\bar{x}=172.3 \pm 98.8 \mathrm{~km}, n=15$ species) (Fig. 1) and most of these shifts (13 of 15) were northward (Table 1). The spatial temperature gradient of the North Sea is somewhat unusual; water temperatures become colder with increasing latitude in the southern North Sea but become slightly warmer with increasing latitudes in the north (8), where warm North Atlantic Current waters enter the region (9). This temperature pattern may explain one of the two exceptional species that moved south, the Norway pout (Trisopterus esmarkii). Its distribution was centered in the northern North Sea, and its southern movement brought it into cooler waters. The other exception was the common sole. We speculate that the southward shift in its distribution may have been caused by the fact that the cleanup of the Thames estuary led to its emergence as a major sole nursery ground during the study period (10).

Most species that showed climate-related latitudinal changes also shifted in depth, which was unsurprising because North Sea depths are roughly positively correlated with latitude $(8)$. A further six species, including plaice (Pleuronectes platessa) and cuckoo ray (Leucoraja

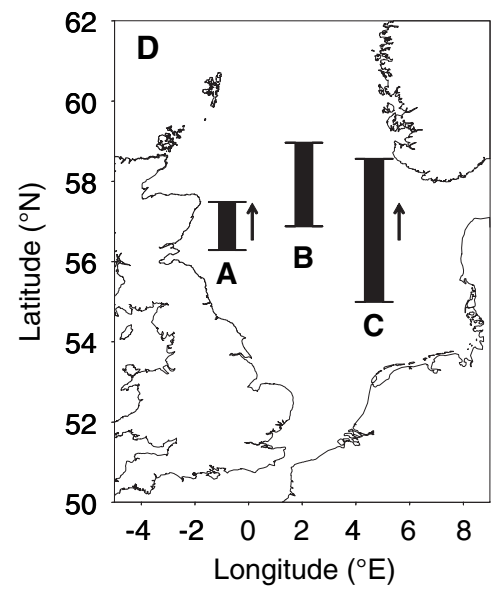

Fig. 1. Examples of North Sea fish distributions that have shifted north with climatic warming. Relationships between mean latitude and 5-year running mean winter bottom temperature for (A) cod, (B) anglerfish, and $(C)$ snake blenny are shown. In (D), ranges of shifts in mean latitude are shown for (A), (B), and (C) within the North Sea. Bars on the map illustrate only shift ranges of mean latitudes, not longitudes. Arrows indicate where shifts have been significant over time, with the direction of movement. Regression details are in Table 1. 
naevus), moved deeper with warming but did not change in latitude, suggesting that they may have responded to climatic variation through local movements offshore or into pockets of deeper water. Considering both latitude and depth, nearly two-thirds of species $(n=21$ out of 36) have shown distributional responses to climatic warming (table S1).

We tested whether species boundaries have also been displaced by warming, by examining those 20 species from our data set with a southern or a northern range limit in the North Sea. The boundaries of half of these fishes moved significantly with warming (Fig. 2 and table S2). Southern boundaries shifted in 6 of 12 cases, and all shifts were northward. Four of eight northern boundaries also moved with warming. All but one of these species shifted north, despite the fact that their northern range limits lay in the relatively intensively fished southern North Sea (11). Shifting species again included both exploited and nonexploited fishes. Boundaries moved over distances ranging from 119 to $816 \mathrm{~km}(\bar{x}=304 \pm 196 \mathrm{~km}, n=10)$, with the highest value describing the range of movement of the southern boundary of blue whiting (Micromesistius poutassou), which is the target of the largest fishery in the Atlantic (12). In the case of bib (Trisopterus luscus), the northern boundary shifted by $342 \mathrm{~km}$ from 1978 to 2001, a trend that is supported by observations that North Sea catches of this species have been increasing (13).

To identify shifts that may have been driven by fishing or other nonclimatic influences, we also examined distribution changes over time. Fishing pressure could not be included explicitly in our analyses because reliable fishing effort data on a comparable spatial and temporal scale do not exist for the North Sea. However, during at least the last decade of the 25-year period of analysis, the spatial distribution of effort remained relatively constant (11), and total fishing effort may have declined slightly (14). Temporal trends in distribution suggested that fishing alone could not explain climate-related shifts; despite the gen- eral increase in temperature over the study period, warming-related shifts occurred independently of time for centers of distribution in 8 of 36 species and for range limits in 4 of 20 species (table S3). Such shifts may have reflected year-to-year environmental variability, with northward movement during warm years cancelled by southward movement during cool years. If so, long-term distribution shifts could depend strongly on future climatic variability, in addition to longer-term average conditions.

The examination of temporal trends also allowed for rough comparisons to be drawn with rates of warming-related distribution shifts in other taxa. A recent meta-analysis of climatechange impacts on natural systems estimated the mean annual rate of boundary movement for 99 species of birds, butterflies, and alpine herbs at $0.6 \mathrm{~km}$ northward or $0.6 \mathrm{~m}$ upward (1). From the current study, the mean rate of movement for the six fish species whose boundaries shifted in relation to both climate and time [bib, blue whiting, lesser weever
Table 1. Statistically significant multiple regressions of the effects of three measures of North Sea warming on mean latitudes of 36 demersal fishes from 1977 to 2001. PC1, first principal component from principal components anal- ysis (PCA) of eight environmental variables (PC1 generally describes warming). Winter temp. and summer temp. indicate 5 -year running mean bottom temperatures for December to March and June to September, respectively.

\begin{tabular}{|c|c|c|c|c|c|c|c|c|c|c|c|c|c|}
\hline Species & Common name & $\mathrm{df}$ & $\begin{array}{c}\text { Mean } \\
\text { latitude } \\
\left({ }^{\circ} \mathrm{N}\right)\end{array}$ & SD & PC1 & $r^{2}$ & $P$ & $\begin{array}{l}\text { Winter } \\
\text { temp. }\end{array}$ & $r^{2}$ & $P$ & $\begin{array}{l}\text { Summer } \\
\text { temp. }\end{array}$ & $r^{2}$ & $P$ \\
\hline Agonus cataphractus & Pogge & 22 & 54.67 & 0.90 & & & & & & & & & \\
\hline Anarhichus lupus & Atlantic wolffish & 21 & 58.14 & 0.46 & & & & & & & & & \\
\hline Argentina spp. & Argentines & 24 & 59.59 & 0.30 & & & & & & & & & \\
\hline Arnoglossus laterna & Scaldfish & 15 & 54.17 & 0.31 & & & & 0.456 & 0.43 & 0.006 & & & \\
\hline Buglossidium luteum & Solenette & 23 & 54.14 & 0.28 & & & & & & & & & \\
\hline Callionymus lyra & Dragonet & 23 & 55.40 & 0.65 & 0.265 & 0.16 & 0.049 & 0.937 & 0.34 & 0.002 & & & \\
\hline Echiichthys vipera & Lesser weever & 24 & 53.30 & 0.13 & & & & 0.191 & 0.39 & 0.001 & & & \\
\hline Eutrigla gurnardus & Grey gurnard & 23 & 56.13 & 0.35 & 0.194 & 0.30 & 0.006 & 0.651 & 0.61 & $<0.001$ & 0.402 & 0.17 & 0.040 \\
\hline Gadiculus argenteus & Silvery pout & 23 & 59.83 & 0.41 & & & & & & & & & \\
\hline Gadus morhua & Atlantic cod & 23 & 56.81 & 0.34 & 0.256 & 0.58 & $<0.001$ & 0.534 & $0.38 \dagger$ & $<0.001$ & 0.578 & $0.33 \dagger$ & $<0.001$ \\
\hline Glyptocephalus cynoglossus & Witch & 24 & 58.22 & 0.42 & & & & & & & & & \\
\hline Hippoglossoides platessoides & Long rough dab & 24 & 57.62 & 0.21 & & & & 0.304 & 0.40 & 0.001 & & & \\
\hline Lepidorhombus boscii & Fourspot megrim & 24 & 60.51 & 0.37 & & & & & & & & & \\
\hline Leucoraja naevus & Cuckoo ray & 19 & 58.06 & 0.57 & & & & & & & & & \\
\hline Limanda limanda & Dab & 24 & 55.86 & 0.13 & & & & 0.180 & $0.35 \dagger$ & 0.001 & & & \\
\hline Lophius piscatorius & Anglerfish & 23 & 57.99 & 0.58 & 0.254 & 0.19 & 0.032 & 0.818 & 0.37 & 0.001 & & & \\
\hline Lumpenus lampretaeformis & Snake blenny & 12 & 56.52 & 1.15 & & & & 3.174 & 0.81 & $<0.001$ & & & \\
\hline Melanogrammus aeglefinus & Haddock & 24 & 57.91 & 0.16 & & & & & & & & & \\
\hline Merlangius merlangus & Whiting & 23 & 56.57 & 0.15 & 0.066 & 0.19 & 0.034 & & & & & & \\
\hline Merluccius merluccius & Hake & 24 & 58.84 & 0.59 & & & & & & & & & \\
\hline Micromesistius poutassou & Blue whiting & 21 & 60.13 & 0.48 & & & & & & & & & \\
\hline Microstomus kitt & Lemon sole & 24 & 57.06 & 0.24 & & & & & & & & & \\
\hline Molva molva & Ling & 24 & 59.26 & 0.74 & & & & & & & & & \\
\hline Myxine glutinosa & Hagfish & 11 & 57.51 & 0.62 & & & & & & & & & \\
\hline Pleuronectes platessa & Plaice & 24 & 55.52 & 0.18 & & & & & & & & & \\
\hline Pollachius virens & Saithe & 24 & 59.44 & 0.20 & & & & & & & & & \\
\hline Psetta maxima & Turbot & 13 & 54.73 & 0.31 & & & & & & & & & \\
\hline Rhinonemus cimbrius & Four-bearded rockling & 22 & 56.05 & 0.68 & 0.419 & 0.40 & 0.001 & 1.147 & 0.53 & $<0.001$ & 0.950 & 0.28 & 0.008 \\
\hline Scyliorhinus canicula & Small-spotted catshark & 20 & 58.34 & 0.89 & & & & & & & & & \\
\hline Sebastes spp. & Redfish & 18 & 59.89 & 0.49 & & & & & & & & & \\
\hline Solea solea & Common sole & 13 & 53.68 & 0.66 & & & & -0.941 & 0.38 & 0.020 & -0.963 & 0.34 & 0.028 \\
\hline Squalus acanthias & Spurdog & 19 & 56.29 & 0.68 & & & & & & & & & \\
\hline Trigla lucerna & Tub gurnard & 19 & 53.89 & 0.50 & & & & & & & & & \\
\hline Trisopterus esmarkii & Norway pout & 23 & 58.59 & 0.26 & -0.190 & 0.52 & $<0.001$ & -0.304 & 0.25 & 0.010 & -0.429 & 0.37 & 0.001 \\
\hline Trisopterus luscus & Bib & 9 & 53.29 & 0.51 & & & & $0.489 *$ & 0.45 & 0.035 & & & \\
\hline Trisopterus minutus & Poor cod & 23 & 55.63 & 0.66 & 0.334 & 0.26 & 0.012 & 0.877 & 0.33 & 0.003 & 0.753 & 0.18 & 0.035 \\
\hline
\end{tabular}

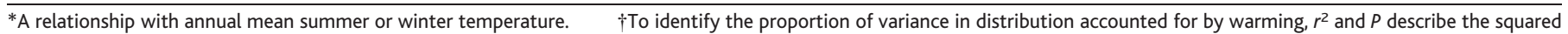
semi-partial correlation coefficient, where abundance was also a significant predictor of distribution. 


\section{R E P O R T S}

(Echiichthys vipera), Norway pout, scaldfish, and witch (Glyptocephalus cynoglossus)] was $2.2 \mathrm{~km}$ per year. It is perhaps
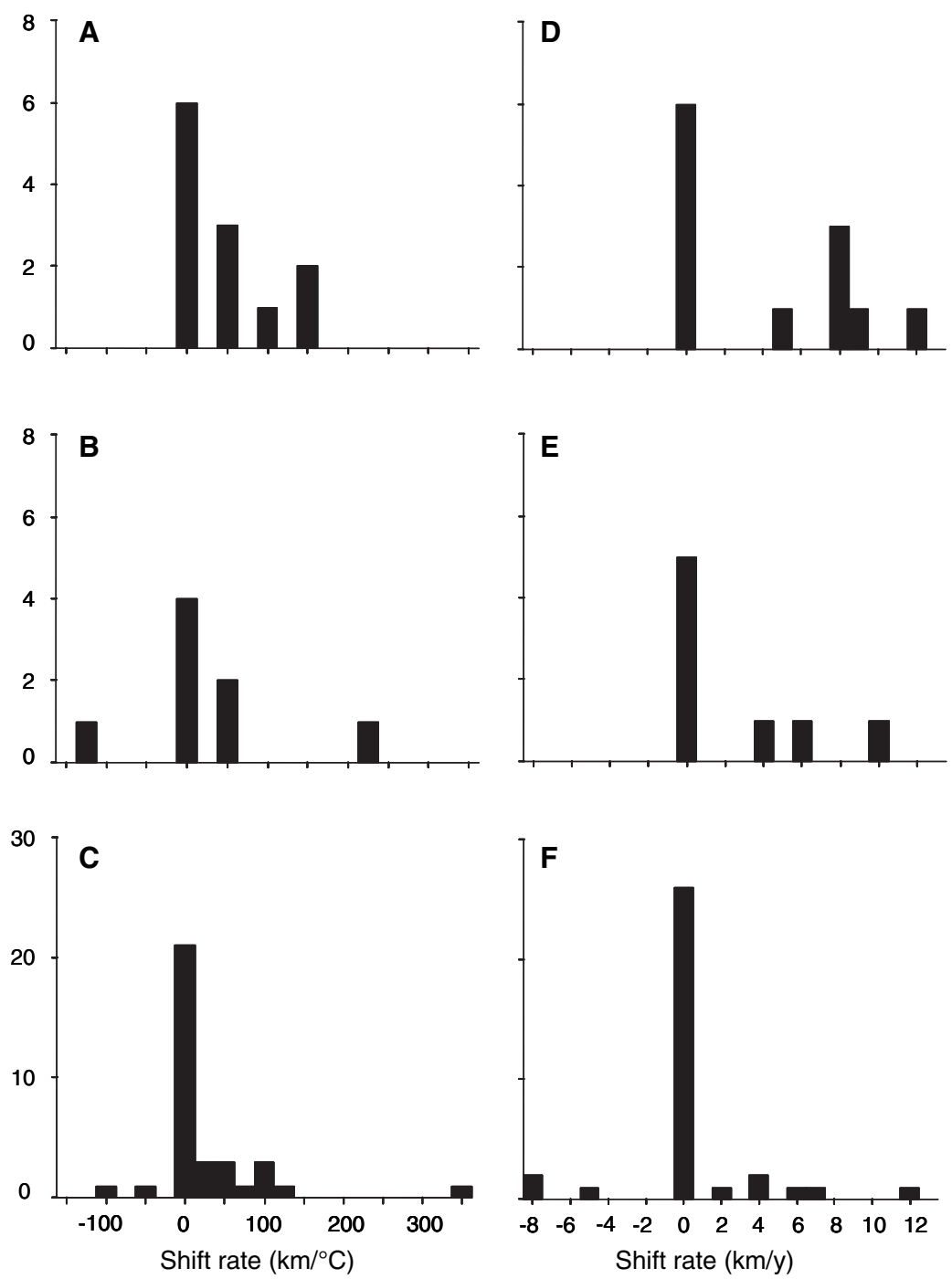

Fig. 2. Frequency distributions of fish species shift rates in relation to warming and time. (A) Rates of shift for northerly species' (southern) boundaries with climate. (B) Southerly species' (northern) boundaries with climate. (C) All species' mean latitudes with climate. (D) Northerly species'(southern) boundaries over time. (E) Southerly species' (northern) boundaries over time. (F) All species' mean latitudes over time. Rates for shifting species are slopes from regressions.
A

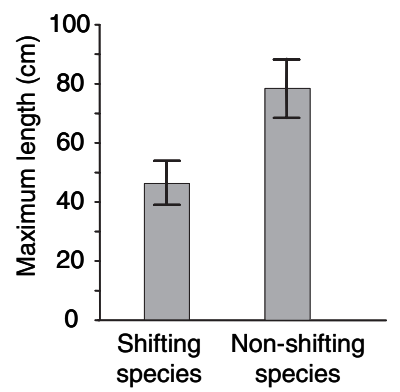

B

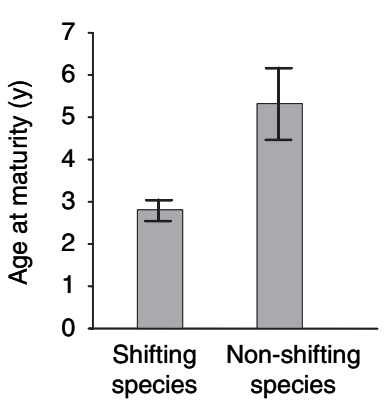

C

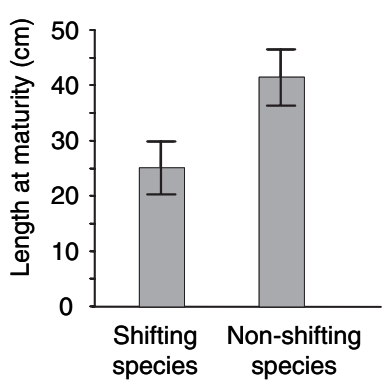

Fig. 3. Differences in life-history traits between shifting $(n=15)$ and nonshifting $(n=21)$ species with respect to centers of distribution (mean latitudes). (A) Maximum body size $[t=-2.41$, degrees of freedom $(\mathrm{df})=34, P=0.02]$. (B) Age at maturity $(t=-2.86, \mathrm{df}=27, P=0.01)$. (C) Length at maturity $(t=-2.29$, df $=29, P=0.03)$. Means are shown with standard errors. generally face fewer constraints on movement. However, if such a difference is indicative of more widespread trends in marine fishes, climate change could pose a greater threat to fish populations that are constrained by their dispersal capabilities or habitat requirements.

If the differences in rates of movement among the taxa documented here result from differential rates of population turnover, we would expect species with life history traits associated with fast population growth to have responded most strongly to climate change. To test this prediction, we compared life history traits between shifting and nonshifting species (7). As predicted, shifting species tend to have faster life histories than do nonshifting species, with significantly smaller body sizes, faster maturation, and smaller sizes at maturity (Fig. 3). Body growth rates did not differ significantly between shifting and nonshifting species $(P=0.19)$. These relationships therefore provide a starting point for predicting species' responses to future climate change. These predictions could be refined, through detailed studies of the relative sensitivities of different life history stages, to uncover the specific mechanisms driving the patterns.

Our study shows that climate change is having detectable impacts on marine fish distributions, and observed rates of boundary movement with warming indicate that future distribution shifts could be pronounced. Mean annual surface temperatures in the North Sea are predicted to increase by 0.5 to $1.0^{\circ} \mathrm{C}$ by $2020,1.0$ to $2.5^{\circ} \mathrm{C}$ by 2050 , and 1.5 to $4.0^{\circ} \mathrm{C}$ by 2080 (15). We used the midpoints of these temperature ranges as the basis for a rough approximation, which suggested that two types of commercial fishes, blue whiting and redfishes (Sebastes spp.), may retract completely from the North Sea by 2050, and by 2080 , bib may extend its range northward to encompass the entire region. Such changes will clearly also depend on the responses of their predators and prey to increases in bottom temperature and on the availability of suitable habitat.

These findings may have important impacts on fisheries. For example, species with slower life histories are already more vulnerable to overexploitation (16-18) and may also be less able to compensate for warming through rapid demographic responses. A further concern is that differential rates of shift could result in altered spatial overlap among species, thereby disrupting interactions and also potentially compounding the decoupling effects of climate-driven changes in phenology (19). Previous work off the eastern United States has shown that fishes with the most temperature-sensitive distributions included key prey species of nonshifting predators (20). Such changes could have unpredictable effects in an ecosystem already under heavy anthropogenic pressure. 


\section{References and Notes}

1. C. Parmesan, G. Yohe, Nature 421, 37 (2003).

2. C. D. Thomas et al., Nature 427, 145 (2004).

3. C. M. Wood, D. G. McDonald, Eds., Global Warming: Implications for Freshwater and Marine Fish (Cambridge Univ. Press, Cambridge, 1997).

4. K. Brander et al., Int. Counc. Explor. Sea Mar. Sci. Symp. 219, 261 (2003).

5. G. Beaugrand, K. M. Brander, J. A. Lindley, S. Souissi, P. C. Reid, Nature 426, 661 (2003).

6. G. Beaugrand, P. C. Reid, F. Ibañez, J. A. Lindley, M. Edwards, Science 296, 1692 (2002).

7. Materials and methods are available as supporting material on Science Online.

8. R. J. Knijn, T. W. Boon, H. J. L. Heessen, J. F. G. Hislop, Atlas of North Sea Fishes [International Council for the Exploration of the Sea (ICES) Cooperative Research Report 194, ICES, Copenhagen, 1993].

9. A. N. Strahler, A. H. Strahler, Physical Geography: Science and Systems of the Human Environment (Wiley, New York, 1997).

10. R. M. Thomas, in A Rehabilitated Estuarine Ecosystem: The Environment and Ecology of the Thames Estuary,
M. J. Attrill, Ed. (Kluwer, Dordrecht, Netherlands, 1998), pp. 115-139.

11. S. Jennings et al., Fish. Res. 40, 125 (1999).

12. ICES Advisory Committee on Fishery Management (ACFM), Report of the Northern Pelagic and Blue Whiting Fisheries Working Group (ICES CM 2004/ ACFM:24, ICES, Copenhagen, 2004).

13. S. I. Rogers, J. R. Ellis, Int. Counc. Explor. Sea J. Mar. Sci. 57, 866 (2000).

14. N. Daan, H. Gislason, J. Pope, J. Rice, Changes in the North Sea Fish Community: Evidence of Indirect Effects of Fishing? (ICES CM N:10, ICES, Copenhagen, 2003).

15. U.K. Climate Impacts Programme, UKCIPO2 Scenarios Gateway-Maps Gateway; available at www.ukcip.org. uk/scenarios/marine/marine.html.

16. N. K. Dulvy, Y. Sadovy, J. D. Reynolds, Fish Fish. 4, 25 (2003).

17. S. Jennings, J. D. Reynolds, S. C. Mills, Proc. R. Soc. London Ser. B 265, 333 (1998).

18. J. D. Reynolds, S. Jennings, N. K. Dulvy, in Conservation of Exploited Species, J. D. Reynolds, G. M. Mace, K. H. Redford, J. G. Robinson, Eds. (Cambridge Univ. Press, Cambridge, 2001), pp. 145-168.
19. M. Edwards, A. J. Richardson, Nature 430, 881 (2004).

20. S. A. Murawski, Trans. Am. Fish. Soc. 122, 647 (1993)

21. We thank A. Taylor, P. C. Reid, T. Osborn, P. Jones, the ICES Oceanographic Database, and the UK Climate Impacts Programme for providing data; J. Gill, W. Sutherland, and A. Watkinson for commenting on earlier drafts; and M. Attrill, K. Brander, R. Clark, C. Fox, J. Gill, and S. Jennings for valuable discussion. This research was undertaken under the Defra-funded project MF0730, with additional support from a Commonwealth Scholarship to A.L.P. and an NERC grant to J.D.R.

\section{Supporting Online Material}

www.sciencemag.org/cgi/content/full/1111322/DC1

Materials and Methods

Tables S1 to S4

References

22 February 2005; accepted 28 April 2005

Published online 12 May 2005:

10.1126/science. 1111322

Include this information when citing this paper. 


\section{Supporting Online Material}

\section{Materials and Methods}

Data

Annual data describing demersal fish distribution and abundance in the North Sea (between $51-62^{\circ}$ latitude) from 1977-2001 were taken from the English Groundfish Survey (EGFS) programme. Species were included in analyses if they were caught at a minimum of five stations each year, during at least ten years. Blue whiting (Micromesistius poutassou), although not considered a demersal fish, was retained in the dataset because the EGFS is considered to sample this species effectively in the North Sea. In accordance with EGFS records, redfishes (Sebastes spp.) were combined, as were argentines (Argentina silus and A. sphyraena). Abundance-weighted mean annual latitudes and depths were derived for each species. For fishes with northern or southern range limits in the North Sea, abundance-weighted annual boundary latitudes were also calculated, based on the three most extreme stations of occurrence in each year.

Bottom temperature data were obtained from the International Council for the Exploration of the Sea, for $1^{\circ} \times 1^{\circ}$ boxes in the North Sea. Annual means and five-year running means (to allow for potential lagged effects) were calculated for winter (the four coldest months, December-March) and summer (the four warmest months, JuneSeptember). Data on the winter North Atlantic Oscillation Index (NAOI) (the normalised sea level pressure difference between Gibraltar and Reykjavik, Iceland), which is associated with changes in fish abundance, growth, and productivity $(S 1, S 2)$ were from Jones et al. (S3), with updated values provided by the Climatic Research Unit, University of East Anglia (S4). Gulf Stream Index (GSI) data (measuring the relative extent of the northern wall of the Gulf Stream along the east coast of North 
America) were obtained from the Plymouth Marine Laboratory (S5). Average annual abundances of the calanoid copepod species Calanus helgolandicus and $C$.

finmarchicus (which are major food sources for many juvenile fish) (S6), were provided by the Sir Alister Hardy Foundation for Ocean Science.

Life history parameter estimates were compiled from the primary literature, FishBase $(S 7)$, and regional fish guides $(S 8, S 9)$. Growth rates and maximum lengths were described as $K$ and $L_{\infty}$ from the von Bertalanffy growth equation, $L_{t}=L_{\infty}\left(1-e^{-K\left(t-t_{0}\right)}\right)$ (where $L_{t}$ is length at age $t, L_{\infty}$ is the asymptotic length at which growth rate is theoretically zero, $K$ is the rate of growth towards this asymptote, and $t_{0}$ is the age at which length would theoretically have been zero $(S 10))$. Maximum observed length $\left(L_{\max }\right)$ was included, because it was available for more species than $L_{\infty}$, and serves as a useful surrogate for $L_{\infty}(S 11)$. We also used mean age and length at maturity ( $T_{\text {mat }}$, and $L_{\text {mat }}$ ) for $50 \%$ of the population. For parameter estimates and references, see Table S4. Values were used for North Sea populations where possible, and otherwise were selected for the closest available region. Means were calculated where sex-specific values were reported or multiple estimates were available, and mean values were also used for the combined redfish and argentine species.

\section{Statistical analyses}

In order to assess the direct effects of warming on species distributions, winter and summer temperatures (same-year and five-year running means) and abundance were entered into multiple regressions for each species, using (a) mean latitude (b) mean depth and, where applicable, (c) boundary latitude as dependent variables. Where significant models included both abundance and environmental predictors, semi-partial correlation coefficients were examined to determine the relative influence of warming. 
We also examined less direct effects of warming on distributions, through multiple regressions in which we again controlled for changes in abundance and regressed the distribution variables against composite variables of warming rather than temperatures. These new variables were the first and second factors from a Principal Components Analysis of eight environmental variables that generally described warming (winter temperature, five-year running mean winter temperature, summer temperature, five-year running mean summer temperature, NAOI, NAOI with a 1-year lag, GSI, and the ratio of C. helgolandicus abundance: C. finmarchicus abundance) and were correlated with the position of species centres and boundaries. The first principal component (PC1) explained $47 \%$ of the variance in these variables, and generally described warming. PC2 accounted for a further $18 \%$ of the variance. Finally, we used simple linear regression to examine changes in mean latitudes and boundary latitudes over time.

We tested for life history differences between species whose mean latitudes shifted and did not shift in relation to warming. Small sample sizes limited the use of phylogenetically paired comparisons, although life history differences lay in the expected direction for 6 of 9 pairs.

The effects of using mean values for life history parameters estimates for redfishes and argentines were checked by redoing analyses using values for individual species from each group, and by excluding these groups altogether. None of these variations altered our findings. 


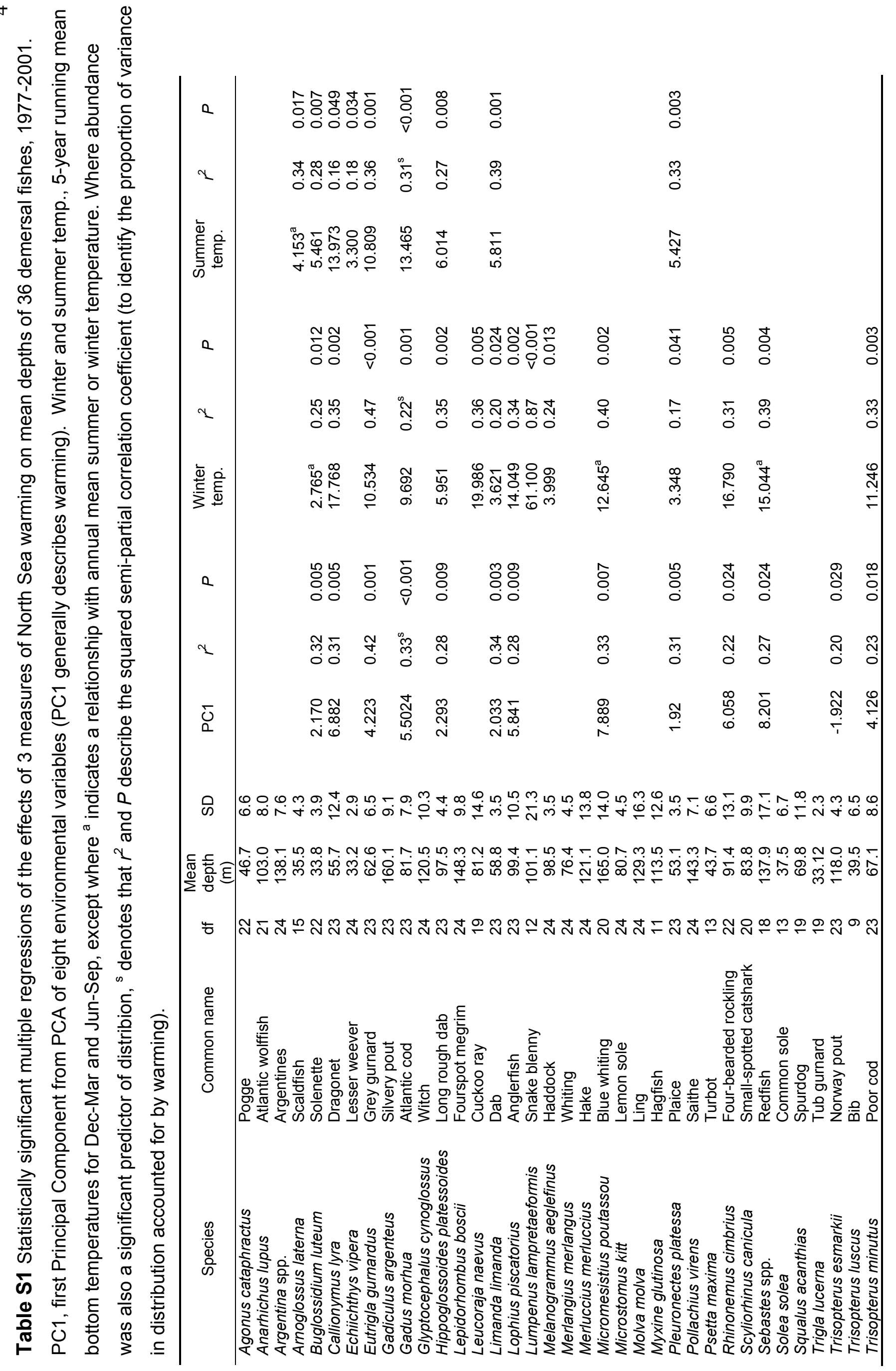




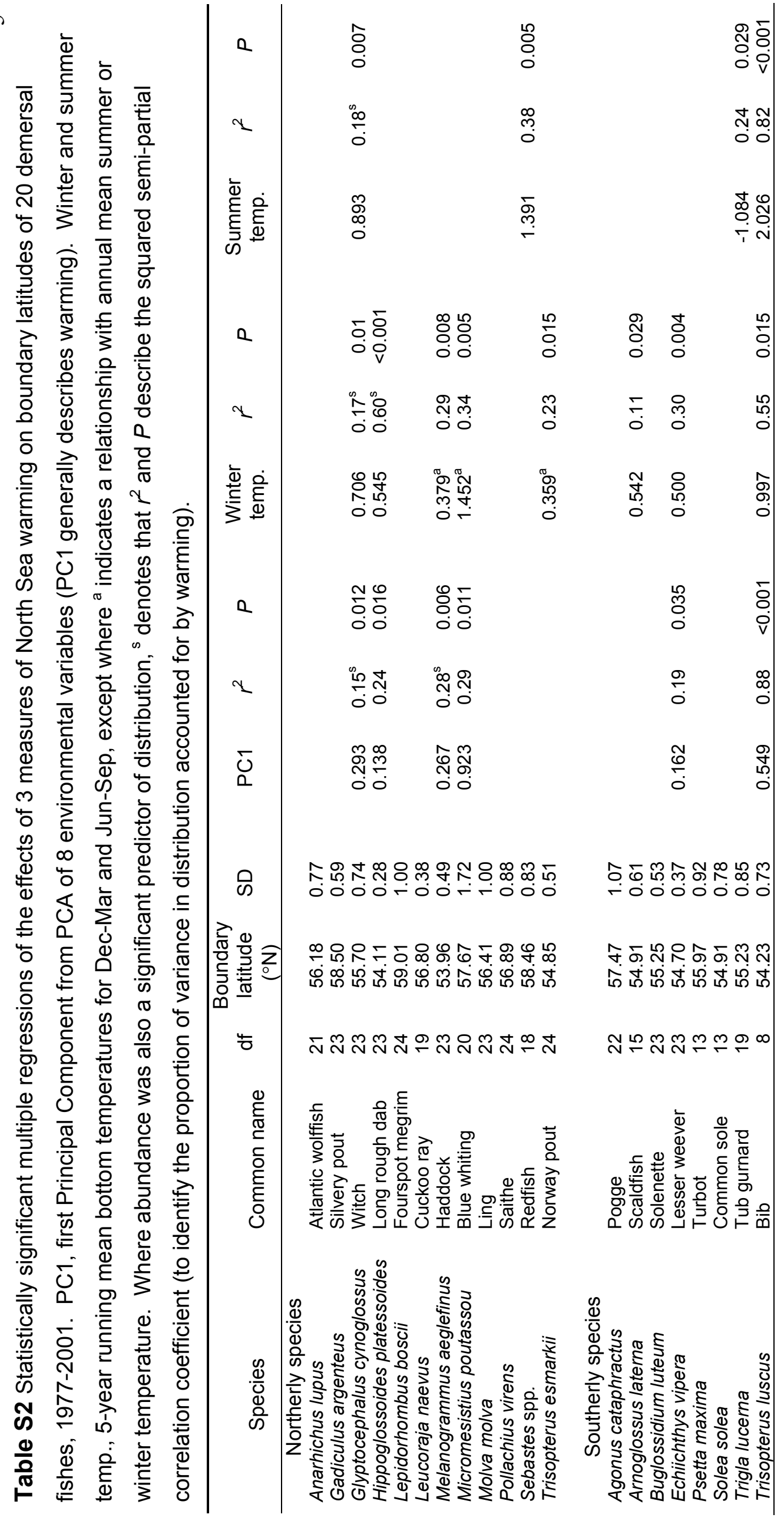




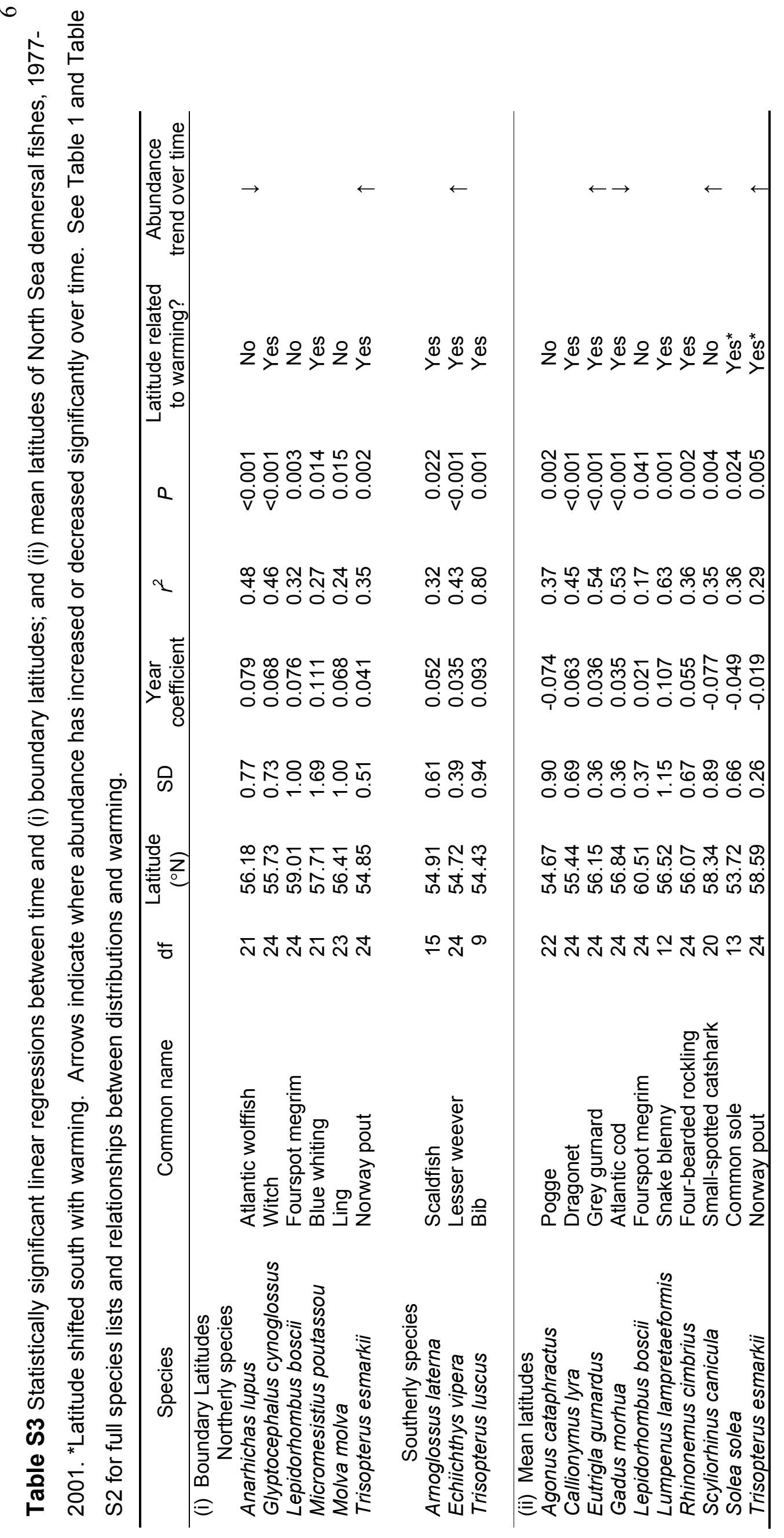


Table S4 Life history parameter estimates for 36 North Sea demersal fish species. $L_{\infty}$, asymptotic (maximum) length; $K$, growth rate from the von Bertalanffy equation; $L_{\max }$, maximum recorded length; $T_{\text {mat, }}$ age at which $50 \%$ of the population are mature; $L_{\text {mat }}$ length at which $50 \%$ of the population are mature.

\begin{tabular}{|c|c|c|c|c|c|c|c|}
\hline Species & Common Name & $\begin{array}{c}L_{\infty} \\
(\mathrm{cm})\end{array}$ & $\begin{array}{l}L_{\max } \\
(\mathrm{cm})\end{array}$ & $\begin{array}{c}K \\
\left(y^{-1}\right)\end{array}$ & $\begin{array}{l}T_{\text {mat }} \\
\text { (y) }\end{array}$ & $\begin{array}{l}L_{\text {mat }} \\
(\mathrm{cm})\end{array}$ & References \\
\hline Agonus cataphractus & Pogge & 15 & 20 & 0.475 & . & . & S8, S12, S13 \\
\hline Anarhichas lupus & Atlantic wolffish & 162.5 & 125 & 0.0435 & 6.5 & 55 & S8, S14 \\
\hline Arnoglossus laterna & Scaldfish & 15 & 25 & 0.936 & . & 6.8 & $S 8, S 15, S 16$ \\
\hline Buglossidium luteum & Solenette & 10.75 & 12.5 & 0.573 & 3 & 7 & S8, S15, S17 \\
\hline Callionymus /yra & Dragonet & 23 & 25 & 0.47 & 2.5 & 13 & S8, S18 \\
\hline Echiichthys vipera & Lesser weever & & 17 & . & & . & S19 \\
\hline Eutrigla gurnardus & Grey gurnard & 46 & 45 & 0.16 & 3 & 23 & S8, 520 \\
\hline Gadiculus argenteus & Silvery pout & 15.5 & 15 & 0.693 & & . & $S 8, S 21$ \\
\hline Gadus morhua & Atlantic cod & 123.1 & 131.8 & 0.23 & 3.8 & 69.7 & $S 11, S 22$ \\
\hline Glyptocephalus cynoglossus & Witch & 44 & 60 & 0.2 & 4.5 & 29 & $s 20$ \\
\hline Hippoglossoides platessoides & Long rough dab & 25 & 30 & 0.34 & 2.6 & 15 & S7, S20 \\
\hline Lepidorhombus boscii & Fourspot megrim & 50 & 35 & 0.155 & 1.5 & . & $S 7, S 23, S 24$ \\
\hline Leucoraja naevus & Cuckoo ray & 92 & 70 & 0.11 & 9 & 59 & S8, S20 \\
\hline Limanda limanda & $\mathrm{Dab}$ & 27 & 40 & 0.26 & 2.3 & 13 & $S 8,520$ \\
\hline Lophius piscatorius & Anglerfish & 106 & 74.6 & 0.18 & 4.5 & 61 & $S 11, S 20$ \\
\hline Lumpenus lampretaeformis & Snake blenny & & 50 & . & 3 & 20 & S8 \\
\hline Melanogrammus aeglefinus & Haddock & 68.3 & 75.5 & 0.19 & 2.5 & 33.5 & $S 22$ \\
\hline Merlangius merlangus & Whiting & 42.4 & 44.9 & 0.32 & 1.5 & 20.2 & $S 11, S 22$ \\
\hline Merluccius merluccius & Hake & 105 & 135 & 0.184 & 6.75 & 51.75 & S8, S25 \\
\hline Micromesistius poutassou & Blue whiting & 37.1 & 34 & 0.23 & 2.3 & 25.1 & S7, S22 \\
\hline Microstomus kitt & Lemon sole & 37 & 60 & 0.42 & 4 & 27 & s8, S20, S26 \\
\hline Molva molva & Ling & 183 & 200 & 0.118 & 6.5 & 90 & S8, S27 \\
\hline Myxine glutinosa & Hagfish & & 80 & . & & 25 & S8 \\
\hline Pleuronectes platessa & Plaice & 54.5 & 95 & 0.11 & 2.5 & 26.6 & S8, S22 \\
\hline Pollachius virens & Saithe & 177.1 & 130 & 0.07 & 4.6 & 55.4 & S8, S22 \\
\hline Psetta maxima & Turbot & 69.6 & 100 & 0.2497 & 4.5 & 49 & $S 8, S 15, S 17, S 28$ \\
\hline Rhinonemus cimbrius & Four-bearded rockling & 36 & 40 & 0.2 & 3 & 25 & S8, S20 \\
\hline Scyliorhinus canicula & Small-spotted catshark & 88 & 100 & 0.2 & 5 & 58 & S8, S20 \\
\hline Sebastes marinus & Redfish & 74.4 & 100 & 0.0615 & 11 & 35 & S8, S29 \\
\hline Sebastes viviparus & Norway haddock & 36 & 35 & 0.07 & 20 & 12.5 & S8, S20 \\
\hline Solea solea & Common sole & 45.3 & 60 & 0.363 & 4 & 29 & S8, S15 \\
\hline Squalus acanthias & Spurdog & 90 & 105 & 0.15 & 6.5 & 67 & S8, S20 \\
\hline Trigla lucerna & Tub gurnard & 68.15 & 75 & 0.1524 & . & . & s8, s30, s31 \\
\hline Trisopterus esmarkii & Norway pout & 23 & 25 & 0.52 & 2.3 & 19 & S8, S22 \\
\hline Trisopterus luscus & Bib & 42.35 & 46 & 0.211 & 2 & 22.5 & S17, S32 \\
\hline Trisopterus minutus & Poor cod & 20 & 40 & 0.51 & 2 & 15 & S8, S2O \\
\hline
\end{tabular}




\section{References}

S1. M. J. Attrill, M. Power, Nature 417, 275 (2002).

S2. G. Ottersen et al., Oecologia 128, 1 (2001).

S3. P. D. Jones, T. Jónsson, D. Wheeler, Int. J. Climatol. 17, 1433 (1997).

S4. T. Osborn, North Atlantic Oscillation (www.cru.uea.ac.uk/ timo/projpages/nao_update.htm, 2002).

S5. A. H. Taylor, Latitude of the Gulf Stream (www.pml.ac.uk/gulfstream, 2002).

S6. $\quad$ L. S. Parsons, W. H. Lear, Prog. Oceanogr. 49, 167 (2001).

S7. R. Froese, D. Pauly, FishBase (www.fishbase.org, 2002).

S8. B. J. Muus, J. G. Nielson, Sea Fish (Scandinavian Fishing Year Book, Hedehusene, Denmark, 1999).

S9. $\quad$ P. J. Miller, M. J. Loates, Fish of Britain and Europe (Harper Collins, London, 1997).

S10. R. J. H. Beverton, S. J. Holt, On the Dynamics of Exploited Fish Populations (Ministry of Agriculture, Fisheries and Food, London, 1957).

S11. N. H. Denney, S. Jennings, J. D. Reynolds, Proc. R. Soc. London Ser. B 269, 2229 (2002).

S12. S. Le Gall, Vie milieu 20A, 153 (1969).

S13. E. Ehrenbaum, Eier und Larven von Fischen. Nordisches Plankton (Lipsius \& Tischer, Kiel, 1905).

S14. G. Beese, R. Kändler, Ber. Deut. Wiss. Komm. 20, 21 (1969).

S15. C. Déniel, J. Fish Biol. 37, 149 (1990).

S16. O. Giovanardi, C. Piccinetti, "Biology and fishery of the scaldfish Arnoglossus laterna (Walbaum 1792) in the Adriatic Sea" (FAO Fish. Rep. 290, FAO, Rome, 1983).

S17. R. J. Knijn, T. W. Boon, H. J. L Heessen, J. F. G. Hislop, "Atlas of North Sea Fishes" (ICES Coop. Res. Rep. 194, ICES, Copenhagen, 1993).

S18. H. W. van der Veer et al., Neth. J. Sea Res. 26, 139 (1990).

S19. E. Tortonese, in Checklist of the fishes of the north-eastern Atlantic and of the Mediterranean (CLOFNAM), J. C. Hureau, T. Monod, Eds., vol II, (UNESCO, Paris, 1986), pp. 951-954

S20. S. Jennings, S. P. R. Greenstreet, J. D. Reynolds, J. Anim. Ecol. 68, 617 (1999).

S21. R. Letaconnoux, Bull.Inst. Océanogr. 913 (1947).

S22. S. Jennings, J. D. Reynolds, S. C. Mills, Proc. R. Soc. London Ser. B 265, 333 (1998).

S23. R. Castilho, M. T. Dinis, K. Erzini, Fish. Res. 16, 339 (1993).

S24. J. R. Fuertes, Invest. Pesq. 42, 241 (1978).

S25. G. Belloc, Rev. Trav. Inst. Pêch. Marit. 2, 231 (1929).

S26. B. B. Rae, The Lemon Sole (Fishing News, London, 1965).

S27. G. Joenoes, Ber. Deut. Wiss. Komm.16, 129 (1961).

S28. T. Mengi, Ber. Deut. Wiss. Komm. 7, 119 (1963).

S29. V. I. Travin, Dok. Akad. Nauk. SSSR 77, 741 (1951).

S30. J. Collignon, Bull. Inst. Pêch. Maroc 16, 3 (1968).

S31. C. Papaconstantinou, et al., "Investigations on the abundance and distribution of demersal stocks of primary importance in the Thermatikos Gulf and the Thracian Sea (Hellas)" (Tech. Rep., North Aegean Sea Series 4., National Centre for Marine Research, Athens, 1994).

S32. U. Labarta, M.J. Ferreiro, "Age and growth of the Galician coast pouting (Trisopterus luscus L.). Preliminary data.” (ICES C.M. G:65, ICES, Copenhagen, 1982). 